\title{
A Possible Primordial Acetyleno/Carboxydotrophic Core Metabolism
}

\author{
Jessica Sobotta ${ }^{1,+}$, Thomas Geisberger ${ }^{1, \dagger}{ }^{\dagger}$ Carolin Moosmann ${ }^{1}$, Christopher M. Scheidler ${ }^{1}$, \\ Wolfgang Eisenreich ${ }^{1}$, Günter Wächtershäuser ${ }^{2}$ and Claudia Huber 1,*(D) \\ 1 Lehrstuhl für Biochemie, Department Chemie, Technische Universität München, Lichtenbergstraße 4, \\ 85748 Garching, Germany; Jessy.Sobotta@web.de (J.S.); thomas.geisberger@tum.de (T.G.); \\ carolin.moosmann@tum.de (C.M.); christopher.scheidler@cup.lmu.de (C.M.S.); \\ wolfgang.eisenreich@mytum.de (W.E.) \\ 2209 Mill Race Drive, Chapel Hill, NC 27514, USA; gwmunich@bellsouth.net \\ * Correspondence: claudia.huber@tum.de \\ + These authors contributed equally.
}

Received: 9 March 2020; Accepted: 4 April 2020; Published: 7 April 2020

\begin{abstract}
Carbon fixation, in addition to the evolution of metabolism, is a main requirement for the evolution of life. Here, we report a one-pot carbon fixation of acetylene $\left(\mathrm{C}_{2} \mathrm{H}_{2}\right)$ and carbon monoxide $(\mathrm{CO})$ by aqueous nickel sulfide $(\mathrm{NiS})$ under hydrothermal $\left(>100^{\circ} \mathrm{C}\right)$ conditions. A slurry of precipitated NiS converts acetylene and carbon monoxide into a set of $\mathrm{C}_{2-4}$-products that are surprisingly representative for $\mathrm{C}_{2}-4$-segments of all four central $\mathrm{CO}_{2}$-fixation cycles of the domains Bacteria and Archaea, whereby some of the products engage in the same interconversions, as seen in the central $\mathrm{CO}_{2}$-fixation cycles. The results suggest a primordial, chemically predetermined, non-cyclic acetyleno/carboxydotrophic core metabolism. This metabolism is based on aqueous organo-metal chemistry, from which the extant central $\mathrm{CO}_{2}$-fixation cycles based on thioester chemistry would have evolved by piecemeal modifications.
\end{abstract}

Keywords: origin of life; chemical evolution; early metabolism; transition metal catalysis; carbon fixation; nickel sulfide; acetylene; carbon monoxide

\section{Introduction}

All scientific theories concerning the origin and early evolution of life have to consider carbon fixation and the evolution of metabolism. Extant carbon fixation cycles are seen as successors of primordial carbon fixation, and their evolutionary history has been reconstructed as a "phylometabolic" tree [1]. The extant biosphere mainly owes its existence to $\mathrm{CO}_{2}$-fixation. Scientific theories concerning the origin and early evolution of life are expected to be explanatory for this overarching fact. However, any attempt to project from extant $\mathrm{CO}_{2}$-fixation back to a primitive $\mathrm{CO}_{2}$-based core metabolism as wellspring for all biosynthetic pathways faces severe chemical hurdles. Due to its high chemical stability, the conversion of $\mathrm{CO}_{2}$ into core metabolic constituents mainly requires energy coupling by phosphorylation and thioester formation, as well as a nucleophilic attack by carbanion intermediates, and all that is aggravated by the number of $\mathrm{C}_{1}$-extensions. Despite recent findings of acetate and pyruvate formation from $\mathrm{CO}_{2}$ through inorganic catalysis [2,3], alternative geochemically-available carbon sources should be considered. We chose acetylene and $\mathrm{CO}$ as primordial carbon nutrients with the following benefits: (a) availability in volcanic-hydrothermal settings [4-7]; (b) high chemical reactivity with the avoidance of energy coupling; (c) low C-oxidation numbers; (d) CO also serving as reducing agent; (e) strong ligation to catalytic transition metal centers, notably of $\mathrm{Ni}(\mathrm{Fe}) \mathrm{S}$; (f) propensity to engage in organo-nickel reactions instead of carbanion condensations, (g) acyl-nickel activation 
instead of thioester activation; and (h) $\mathrm{C}_{2}$-extensions by acetylene ligands instead of $\mathrm{C}_{1}$-extensions by $\mathrm{CO}_{2}$, with the consequence of a lessened number of required reaction steps. Our findings may be seen as a hint to the evolution of extant carbon fixation cycles through the suggestion of replacing them through a linear reaction system with the inherent possibility of evolving cyclic reaction systems.

\section{Materials and Methods}

All chemicals were purchased from Sigma Aldrich $\mathrm{GmbH}$ (D-Steinheim) in the highest purity available. Acetylene was purchased from Linde AG (D-Pullach), carbon monoxide 2.5 and argon 4.6 were purchased from Westfalen AG (D-Münster), and ${ }^{13} \mathrm{CO}$ was purchased from Cambridge Isotopes Laboratories Inc. (Tewksbury, MA, USA).

In a typical run, a $125 \mathrm{~mL}$ glass serum bottle was charged with 0.5 or $1.0 \mathrm{mmol} \mathrm{NiSO} 4 \bullet 6 \mathrm{H}_{2} \mathrm{O}$ and closed with a silicon stopper. Additionally, $0.5 \mathrm{mmol} \beta-\mathrm{Ni}(\mathrm{OH})_{2}$ or $0.5 \mathrm{mmol} \mathrm{FeSO}{ }_{4} \bullet 7 \mathrm{H}_{2} \mathrm{O}$ was charged in run $\mathrm{B}$ or $\mathrm{D}$ (Table 1), respectively. To achieve a constant ion strength, run $\mathrm{B}$ was supplemented with $0.5 \mathrm{mmol} \mathrm{Na}_{2} \mathrm{SO}_{4}$. The bottle was evacuated three times and filled with argon, finally ending in a deaerated state. Subsequently, the bottle was charged with argon-saturated water (calculated for a final volume of $5 \mathrm{~mL}$ ), with 0.5 or $1.0 \mathrm{~mL}$ argon-saturated $1 \mathrm{M} \mathrm{Na}_{2} \mathrm{~S}$ solution, with $0.5 \mathrm{~mL} 1 \mathrm{M} \mathrm{NaOH}$ solution, and finally with $60 \mathrm{~mL}$ of $\mathrm{CO}$ and $60 \mathrm{~mL}$ of acetylene, using gas-tight syringes for injection. For consecutive reactions, the conditions of run A (see Table 1) were applied, replacing acetylene by $0.5 \mathrm{mmol}$ of the indicated substrates and $60 \mathrm{~mL}$ of $\mathrm{CO}$. To confirm the authenticity of the products, ${ }^{13} \mathrm{CO}$ or $\mathrm{D}_{2} \mathrm{O}$ were used in otherwise identical experiments. Reactions were carried out at $105{ }^{\circ} \mathrm{C}$. After 7 days, the reaction mixture was allowed to cool down and was centrifuged at 10,000 rpm for 5 minutes. The $\mathrm{pH}$ was measured by a glass electrode, and $1 \mathrm{ml}$ of the supernatant was freeze-dried.

For analysis by gas chromatography-mass spectrometry (GC-MS), the residue was dissolved in $250 \mu \mathrm{L}$ of anhydrous acetonitrile and derivatized with $250 \mu \mathrm{L}$ of $N$-tert-butyldimethylsilyl$\mathrm{N}$-methyltrifluoroacetamide (MTBSTFA) for 30 minutes at $70{ }^{\circ} \mathrm{C}$. For the detection of pyruvate, another $\mathrm{ml}$ was freeze dried, and the residue was shaken at $40^{\circ} \mathrm{C}$ for $90 \mathrm{~min}$ in $250 \mu \mathrm{L}$ of pyridine containing $5 \mathrm{mg}$ of $O$-methylhydroxylamine hydrochloride. Afterwards, $250 \mu \mathrm{l}$ of MTBSTFA were added, and the solution was kept at $70{ }^{\circ} \mathrm{C}$ for $30 \mathrm{~min}$. The analysis of the silylated products was performed with GC-MS using GC-2010, coupled with MS-QP2010, Plus (Shimadzu GmbH, D-Duisburg) with a $30 \mathrm{~m} \times 0.25 \mathrm{~mm} \times 0.25 \mu \mathrm{m}$ fused silica capillary column (Equity TM5, Supelco, USA-PA-Bellefonte) and an AOC-20i auto injector. Temperature program and settings:

Program 1 (used for mono silylated products): $0-6 \mathrm{~min}$ at $60^{\circ} \mathrm{C} ; 6-25 \mathrm{~min}$ at $60-280^{\circ} \mathrm{C}, 10^{\circ} \mathrm{C} / \mathrm{min}$; 25-28 min at $280{ }^{\circ} \mathrm{C}$; injector temperature: $260^{\circ} \mathrm{C}$; detector temperature: $260^{\circ} \mathrm{C}$; column flow rate: $1 \mathrm{~mL} / \mathrm{min}$; scan interval: $0.5 \mathrm{sec}$; and injection volume $0.2 \mu \mathrm{L}$.

Program 2 (used for multiple silylated products): $0-6 \mathrm{~min}$ at $90{ }^{\circ} \mathrm{C} ; 6-25 \mathrm{~min}$ at $90-280{ }^{\circ} \mathrm{C}$, $10^{\circ} \mathrm{C} / \mathrm{min}$; and $25-28 \mathrm{~min}$ at $280^{\circ} \mathrm{C}$. Otherwise, identical to program 1 , with an injection volume of $1 \mu \mathrm{L}$. Peak assignment was achieved by a comparison of the retention times and mass spectra of purchased reference compounds, as well as data from the National Institute of Standards and Technology (NIST) spectra library. Quantification was performed by external calibration using known concentrations of commercially-available reference compounds.

In additional experiments for the formation of the thioacetic acid S-methyl ester (methyl thioacetate), a $125 \mathrm{ml}$ serum bottle was charged with $2.0 \mathrm{mmol} \mathrm{NiSO}_{4} \bullet 6 \mathrm{H}_{2} \mathrm{O}$, closed with a silicon stopper, and deaerated as described above. Subsequently, $1.5 \mathrm{ml}$ of $1 \mathrm{M} \mathrm{Na}{ }_{2} \mathrm{~S}, 0.6 \mathrm{~mL}$ of $1 \mathrm{M} \mathrm{NaOH}, 7.9 \mathrm{~mL}$ of $\mathrm{H}_{2} \mathrm{O}, 25 \mathrm{~mL}$ of $\mathrm{CH}_{3} \mathrm{SH}, 90 \mathrm{~mL}$ of $\mathrm{HC} \equiv \mathrm{CH}$ (Table S2 run A), or $45 \mathrm{~mL}$ of $\mathrm{HC} \equiv \mathrm{CH}$ plus $45 \mathrm{~mL}$ of $\mathrm{CO}$ (Table S2 run B) were added. Additional runs were performed with ${ }^{13} \mathrm{CO}$ or deuterated educts. Reactions were carried out at $105^{\circ} \mathrm{C}$. After one day, the reaction mixture was allowed to cool down. For the isolation of methyl thioacetate, $8 \mathrm{ml}$ of the reaction mixture were extracted with $3 \mathrm{~mL}$ of ethyl acetate. The organic phase was dried over $\mathrm{Na}_{2} \mathrm{SO}_{4}$ and analyzed with GC-MS as described above, using an initial oven temperature of $40^{\circ} \mathrm{C}$. The injection volume was $1 \mu \mathrm{L}$. Methyl thioacetate showed a retention time of $2.9 \mathrm{~min}$. 


\section{Results}

We reacted acetylene and carbon monoxide under fastidiously anaerobic, aqueous conditions at the hydrothermally plausible temperature of $105^{\circ} \mathrm{C}$ in the presence of NiS, which was precipitated in situ from $\mathrm{Ni}_{2} \mathrm{SO}_{4}$ with $\mathrm{Na}_{2} \mathrm{~S}$, in the presence or absence $\beta-\mathrm{Ni}(\mathrm{OH})_{2}$. We obtained highly functionalized $\mathrm{C}_{2}-\mathrm{C}_{4}$ products, which are typical for extant carbon fixation cycles (Table 1). Runs with ${ }^{13} \mathrm{CO}$ and $\mathrm{D}_{2} \mathrm{O}$ ascertained that the products were genuine reaction products [8]. For these and further quantified products, GC-MS fragmentations and their isotopic labelling indices are listed in Table S1.

Table 1. Metabolic products of the nickel-catalyzed reaction of acetylene with carbon monoxide. Reactions were carried out in $125 \mathrm{~mL}$ serum bottles with $5 \mathrm{~mL}$ of aqueous liquid phase for 7 days at $105^{\circ} \mathrm{C}$; products were identified by GC-MS as tert-butyldimethylsilyl derivatives. n.d.: not detected.

\begin{tabular}{|c|c|c|c|c|c|}
\hline Runs & & A & B & $\mathrm{C}$ & D \\
\hline $\mathrm{NiSO}_{4} \bullet 6 \mathrm{H}_{2} \mathrm{O}(\mathrm{mmol})$ & & 1.0 & 0.5 & - & 0.5 \\
\hline $\mathrm{FeSO}_{4} \bullet 7 \mathrm{H}_{2} \mathrm{O}(\mathrm{mmol})$ & & - & - & - & 0.5 \\
\hline$\beta-\mathrm{Ni}(\mathrm{OH})_{2}(\mathrm{mmol})$ & & - & 0.5 & 1.0 & - \\
\hline $\mathrm{Na}_{2} \mathrm{SO}_{4}(\mathrm{mmol})$ & & - & 0.5 & 1.0 & - \\
\hline $\mathrm{Na}_{2} \mathrm{~S} \bullet 9 \mathrm{H}_{2} \mathrm{O}(\mathrm{mmol})$ & & 1.0 & 0.5 & - & 1.0 \\
\hline $\mathrm{NaOH}(\mathrm{mmol})$ & & 0.5 & 0.5 & 0.5 & 0.5 \\
\hline $\mathrm{CO}(\mathrm{ml})$ & & 60 & 60 & 60 & 60 \\
\hline $\mathrm{C}_{2} \mathrm{H}_{2}(\mathrm{ml})$ & & 60 & 60 & 60 & 60 \\
\hline pH end & & 8.0 & 8.1 & 9.8 & 8.5 \\
\hline Products $(\mu \mathrm{M})$ & Chemical formula & & & & \\
\hline \multicolumn{6}{|l|}{$\mathrm{C1}$} \\
\hline formate & $\mathrm{HCOO}^{-}$ & 18983 & 24207 & 310 & 434 \\
\hline \multicolumn{6}{|l|}{$\mathrm{C} 2$} \\
\hline acetate & $\mathrm{CH}_{3} \mathrm{COO}^{-}$ & 4358 & 3434 & 112 & 749 \\
\hline glycolate & $\mathrm{HOCH}_{2} \mathrm{COO}^{-}$ & 32 & 38 & n.d. & 11 \\
\hline \multicolumn{6}{|l|}{$\mathrm{C} 3$} \\
\hline acrylate & $\mathrm{CH}_{2} \mathrm{CHCOO}^{-}$ & 9692 & 16874 & 243 & 763 \\
\hline propionate & $\mathrm{CH}_{3} \mathrm{CH}_{2} \mathrm{COO}^{-}$ & 10368 & 15021 & 171 & 339 \\
\hline pyruvate & $\mathrm{CH}_{3} \mathrm{COCOO}^{-}$ & 43 & 117 & n.d. & 4 \\
\hline$\beta$-lactate & $\mathrm{HOCH}_{2} \mathrm{CH}_{2} \mathrm{COO}^{-}$ & 273 & 793 & n.d. & n.d. \\
\hline glycerate & $\mathrm{HOCH}_{2} \mathrm{CH}_{2}(\mathrm{OH}) \mathrm{COO}^{-}$ & 108 & 102 & n.d. & n.d. \\
\hline \multicolumn{6}{|l|}{$\mathrm{C} 4$} \\
\hline crotonate & $\mathrm{CH}_{3} \mathrm{CHCHCOO}^{-}$ & 226 & 516 & n.d. & 22 \\
\hline 2-methylmalonate & $-\mathrm{OOCCH}\left(\mathrm{CH}_{3}\right) \mathrm{COO}^{-}$ & 48 & 145 & n.d. & n.d. \\
\hline maleate & -OOCCHCHCOO- & 72 & 585 & n.d. & 14 \\
\hline succinate & $-\mathrm{OOCCH}_{2} \mathrm{CH}_{2} \mathrm{COO}^{-}$ & 3964 & 4747 & 3 & 187 \\
\hline fumarate & -OOCCHCHCOO- & 358 & 391 & n.d. & 12 \\
\hline malate & ${ }^{-} \mathrm{OOCCH}(\mathrm{OH}) \mathrm{CH}_{2} \mathrm{COO}^{-}$ & 17 & 85 & n.d. & n.d. \\
\hline \multicolumn{6}{|l|}{$\mathrm{C} 5$} \\
\hline (E)-2-methylbut-2-enoate & $\mathrm{CH}_{3} \mathrm{CHC}\left(\mathrm{CH}_{3}\right) \mathrm{COO}^{-}$ & 196 & 411 & n.d. & n.d. \\
\hline$\sum \mathrm{C} 2-\mathrm{C} 5$ & & 29755 & 43259 & 358 & 2101 \\
\hline
\end{tabular}

The detected $\mathrm{C}_{2}$-products acetate and glycolate did not show the ${ }^{13} \mathrm{C}$-label in runs with ${ }^{13} \mathrm{CO}$ and therefore must have been the products of acetylene as the sole carbon source undergoing oxidative addition reactions. $\mathrm{Ni}^{2+}$ ions may have served as the required oxidant, as evidenced by $\mathrm{Ni}^{0}$ particles that have previously been shown to form from $\mathrm{NiS}$ with $\mathrm{CO}$ as reductants under similar conditions [9]. In agreement with a previous proposal [10], the thioacetic acid S-methyl ester (methyl thioacetate) was formed $(2 \mu \mathrm{M}$ in one day) by the reaction of acetylene with methanethiol. A shorter reaction time was 
chosen due to the chemical instability of methyl thioacetate, which is readily hydrolyzed into acetic acid. Under the chosen conditions, CO did not operate as carbon source (Figure S1), but it enhanced the conversion of acetylene into methyl thioacetate, perhaps by ligand effects (Table 2). Methyl thioacetate can be seen as precursor of acetyl-CoA, which is formed by the reductive acetyl-CoA pathway in extant organisms [11]. In Figure S2, the extant acetyl-CoA pathway is compared to the here-described acetylene reaction. In earlier experiments, methyl thioacetate was found to form by the reaction of $\mathrm{CO}$ with methanethiol by $\mathrm{Ni}(\mathrm{Fe}) \mathrm{S}$ catalysis [12]. Methanethiol has been shown to form from $\mathrm{CO}$ with $\mathrm{Ni}(\mathrm{Fe}) \mathrm{S} / \mathrm{H}_{2} \mathrm{~S}$ [12] or from $\mathrm{CO}_{2}$ with $\mathrm{FeS} / \mathrm{H}_{2} \mathrm{~S}$ [13].

Table 2. Formation of methyl thioacetate (thioacetic acid S-methyl ester; $\mathrm{CH}_{3} \mathrm{COSCH}_{3}$ ) from acetylene and methane thiol with or without carbon monoxide. Reactions were carried out in $125 \mathrm{ml}$ serum bottles with $10 \mathrm{ml}$ of aqueous liquid phase for 1 day at $105^{\circ} \mathrm{C}$; methyl thioacetate was identified by GC-MS after ethyl acetate extraction. Labelling in characteristic fragments is shown for runs with $\mathrm{D}_{2} \mathrm{O}$ or ${ }^{13} \mathrm{CO} . \mathrm{n}^{\wedge}$ signifies D-labels, $\mathrm{n} \bullet$ signifies $\mathrm{n}{ }^{13} \mathrm{C}$-labels.

\begin{tabular}{ccccc}
\hline Runs & A & B & Labelling in Characteristic Fragments \\
\hline & & & Mass 1 & Mass 2 \\
\hline $\mathrm{NiSO}_{4} \bullet 6 \mathrm{H}_{2} \mathrm{O}(\mathrm{mmol})$ & 2 & 2 & & \\
$\mathrm{Na}_{2} \mathrm{~S} \bullet 9 \mathrm{H}_{2} \mathrm{O}(\mathrm{mmol})$ & 1.5 & 1.5 & & \\
$\mathrm{NaOH}(\mathrm{mmol})$ & 0.6 & 0.6 & & \\
$\mathrm{C}_{2} \mathrm{H}_{2}(\mathrm{ml})$ & 90 & 45 & & \\
$\mathrm{CO}(\mathrm{ml})$ & - & 45 & & \\
$\mathrm{CH}_{3} \mathrm{SH}(\mathrm{ml})$ & 25 & 25 & & $43 \_3^{\wedge} 0 \bullet$ \\
\hline Methyl thioacetate $(\mu \mathrm{M})$ & $\mathbf{2}$ & $\mathbf{4}$ & $90 \_33^{\wedge} 0 \bullet$ & \\
\hline
\end{tabular}

The formation of the detected organic $>\mathrm{C}_{2}$-products required, not only acetylene but also $\mathrm{CO}$ as carbon source, as evidenced by the ${ }^{13} \mathrm{C}$-labelling (Table S1). If $\mathrm{NiS}$ was precipitated in the presence of $\beta-\mathrm{Ni}(\mathrm{OH})_{2}$, productivity increased significantly, notably from 20 to $32 \mathrm{mM}$ for (acrylate and propionate) or from 4.4 to $5.7 \mathrm{mM}$ for (fumarate, maleate, and succinate) (Table 1 , runs A vs. B). The use of $\beta-\mathrm{Ni}(\mathrm{OH})_{2}$ alone (Table 1, run $\mathrm{C}$ ) or a mixed use of $\mathrm{NiS} / \mathrm{FeS}$ (Table 1 , run $\mathrm{D}$ ) showed only minor product formation. The organic $>\mathrm{C}_{2}$-products had the proper functional groups $(\mathrm{COOH}, \mathrm{CH}=\mathrm{CH}, \mathrm{CO}$, and $\mathrm{CHOH})$ required for core metabolites, from which metabolic pathways could emanate. We detected a set of $C_{2}-C_{4}$ products (acetate, pyruvate, propionate, 3-hydroxy propionate, acrylate, malate, fumarate/maleate, succinate, crotonate, and methyl malonate) that were representative of the (hydrolyzed) constituents of the $\mathrm{C}_{2}-\mathrm{C}_{4}$-segments of the four extant central $\mathrm{CO}_{2}$-fixation cycles of the domains Bacteria and Archaea. In Figure 1, the observed molecules are shown as co-radiating NiS-catalyzed products from acetylene and carbon monoxide, including possible interconversions in the same system. Through overlapping semicircles, these products are assigned to extant pathways. Figures S3-S6 show, in detail, the known carbon fixation cycles in which products from our abiotic system are highlighted by red boxes: the reductive tricarboxylic acid (rTCA) cycle [14] (Figure S3), the 3-hydroxypropionate-4-hydroxybutyrate (3HP-4HB) cycle [15] (Figure S4), the dicarboxylate-4-hydroxybutyrate (DC-4HB) cycle [16] (Figure S5), and the 3-hydroxypropionate (3HP) bicycle [17] (Figure S6). The rTCA cycle has been recognized as being autocatalytic for acetyl-CoA production [18]. The other three $\mathrm{CO}_{2}$-fixation cycles are similarly autocatalytic for acetyl-CoA production and have been recognized for their importance in the evolution of metabolism [19-21]. Remarkably, we also found glycerate and (E)-2-methylbut-2-enoate as entry gates into carbohydrate and isoprenoid metabolisms (Table 1). In total, the here-described $C_{2}-C_{5}$ products summed up to a concentration of $43 \mathrm{mM}$ (run B; Table 1) in the $5 \mathrm{ml}$ setup, which corresponded to about $10 \%$ yield based on acetylene.

Concerning the question of the experimental interconversion of cycle constituents [22-24], we performed experiments with the replacement of acetylene by acrylate, fumarate, malate, and succinate as starting materials under otherwise identical conditions. The reaction products 
of fumarate were succinate, malate and maleate. Acrylate reacted to propionate, $\beta$-lactate, succinate, fumarate, and malate. Malate formed maleate, succinate, and fumarate. Succinate remained mainly unchanged and showed only minor conversion to fumarate and malate (Table 3).

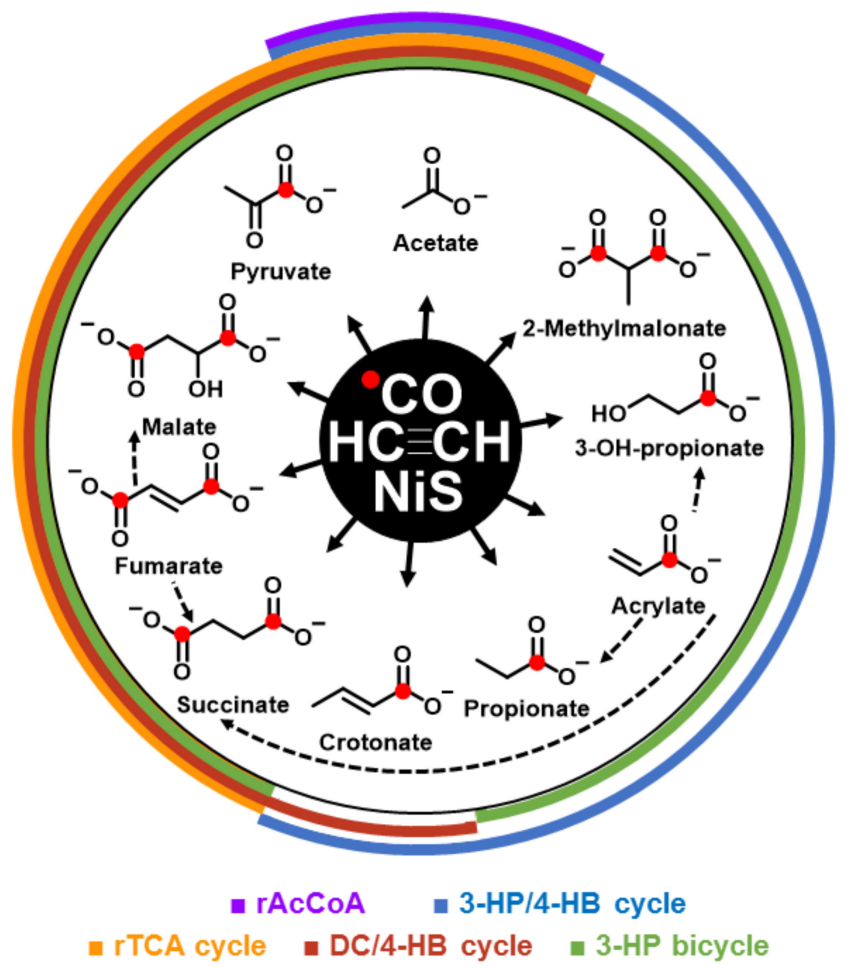

Figure 1. Acetyleno/carboxydotrophic reaction network. NiS-catalyzed reaction network starting from acetylene and carbon monoxide. Observed products are shown with their chemical formula and names; red dots indicate the observed ${ }^{13} \mathrm{C}$ label from ${ }^{13} \mathrm{CO}$. Colored semi cycles signify the corresponding parts of the indicated carbon fixation pathways. (rAcCoA: reductive acetyl-CoA pathway; 3-HP/4-HB cycle: 3-hydroxpropinate/4-hydroxybutyrate cycle; rTCA: reductive tricarboxylic acid cycle; DC/4-HB cycle: dicarboxylate/4-hydroxbutyrate cycle; and 3-HP bicycle: 3-hydroxypropionate bicycle. Dotted arrows show observed interconversions between products of the co-radiating, linear pathways.

Table 3. Consecutive products from selected acids in the presence of CO. Reactions were carried out in $125 \mathrm{~mL}$ serum bottles with $5 \mathrm{~mL}$ of aqueous liquid phase and $120 \mathrm{ml}$ of $\mathrm{CO}$ as gaseous phase for 7 days at $105^{\circ} \mathrm{C}$; further conditions are as described in run A of Table 1, replacing acetylene by $0.5 \mathrm{mmol}$ of the indicated substrates. Products were identified by GC-MS as tert-butyldimethylsilyl derivatives.

\begin{tabular}{cccccc}
\hline Runs & & D & E & F & G \\
\hline Substrate & & fumarate & malate & acrylate & succinate \\
\hline Product (\%) & Chemical formula & & & & \\
\hline acrylate & $\mathrm{CH}_{2} \mathrm{CHCOO}^{-}$ & n.d. & n.d. & 6.37 & n.d. \\
propionate & $\mathrm{CH}_{3} \mathrm{CH}_{2} \mathrm{COO}^{-}$ & n.d. & n.d. & 6.80 & n.d. \\
$\beta$-lactate & $\mathrm{HOCH}_{2} \mathrm{CH}_{2} \mathrm{COO}^{-}$ & n.d. & n.d. & 39.21 & n.d. \\
maleate & $-\mathrm{OOCCHCHCOO}^{-}$ & 2.57 & $\mathbf{0 . 0 2}$ & $\mathbf{0 . 3 1}$ & n.d. \\
succinate & $-\mathrm{OOCCH}_{2} \mathrm{CH}_{2} \mathrm{COO}^{-}$ & $\mathbf{7 1 . 6 7}$ & $\mathbf{1 . 1 3}$ & $\mathbf{4 3 . 8 3}$ & $\mathbf{9 9 . 8 2}$ \\
fumarate & $-\mathrm{OOCCHCHCOO}$ & 21.94 & $\mathbf{0 . 2 4}$ & $\mathbf{1 . 1 4}$ & $\mathbf{0 . 1 4}$ \\
malate & $-\mathrm{OOCCH}(\mathrm{OH}) \mathrm{CH}_{2} \mathrm{COO}^{-}$ & 3.70 & $\mathbf{9 8 . 5 8}$ & $\mathbf{2 . 3 6}$ & $\mathbf{0 . 0 4}$ \\
\hline
\end{tabular}

\section{Discussion}

The chosen reaction conditions (starting materials, catalysts and reaction parameters) are compatible with a variety of scenarios. They fit particularly well to submarine or terrestrial volcanic- 
hydrothermal flow scenarios with late Hadean or early Archaean geochemistry. Acetylene is formed by simulating underwater volcanic activities [4], it is found in fumaroles [5] and on solar planets [6], and it is generated by the hydrolysis of calcium carbide $\left(\mathrm{CaC}_{2}\right)$, which, in turn, is formed by the magmatic reaction of calcium oxide with graphite [7]. Biochemically speaking, acetylene is mainly known as an inhibitor for enzymatic reactions [25] and as a substrate for acetylene hydratase, an FeS enzyme with a tungstopterin cofactor that functions biosynthetically [26], or as detoxifying enzyme [27], and it may be more widespread than previously suspected [28]. Early on, when acetylene abundance would have been greater than today, a precursor of extant acetylene hydratase may have functioned as enzyme for the oxidative addition of $\mathrm{H}_{2} \mathrm{O}$ to acetylene to generate acetyl thioester and glycolate. As evidenced here, these reactions could have proceeded still earlier non-enzymatically in volcanic-hydrothermal vent scenarios. Carbon monoxide is found in volcanic exhalations. At low temperatures, the equilibrium $\mathrm{CO}: \mathrm{CO}_{2}$ molar ratio is low, but higher molar equilibrium ratios at high temperatures and pressures, e.g., 1:1 at $1200,{ }^{\circ} \mathrm{C}$ and 2000, bar [29], could be conserved downstream by quenching [30]. Therefore, a mixture of acetylene and $\mathrm{CO}$ can be seen as a geochemically plausible carbon source for the synthesis of biomolecules under primordial conditions. Iron and nickel are the most abundant transition metals in the crust of the Earth [31], and iron-nickel sulfides are formed at the early stages of crustal evolution [32]. Nickel and iron-nickel centers are still widely spread in extant enzymes and catalyze a variety of reactions [33]. The here-described reactions showed a clear preference to NiS as catalyst, but for evolving further reaction cascades, e.g., reductive amination [34], a mixed FeS/NiS catalyst may be advantageous.

As initial interaction in the here-investigated acetylene/CO/NiS system, we suggest the coordination of acetylene and $\mathrm{CO}$ as ligands to Ni centers. The oxidation of the $\mathrm{CO}$ ligand to $\mathrm{CO}_{2}$ would generate hydride ligands. As next stages, we propose end-on organo-metal adducts between acetylene and one or two Ni centers, hydride transfer, and carbonyl insertion to form highly energetic acyl-[Ni] intermediates [35], which may hydrolyze to carboxylic acids with a total loss of the organo-metal energy. Instead of hydrolysis to free acids, they may react with a mercaptan (or $\mathrm{H}_{2} \mathrm{~S}$ ) to form thioesters (or thioacids) with partial energy conservation (Figure 2). The unsaturated carboxylates (acrylate and fumarate) that result from hydrolysis may subsequently convert by hydrogenation with $\mathrm{CO}$ as reductant to propionate and succinate. The addition of $\mathrm{H}_{2} \mathrm{O}$ may lead to the formation of lactate and malate.

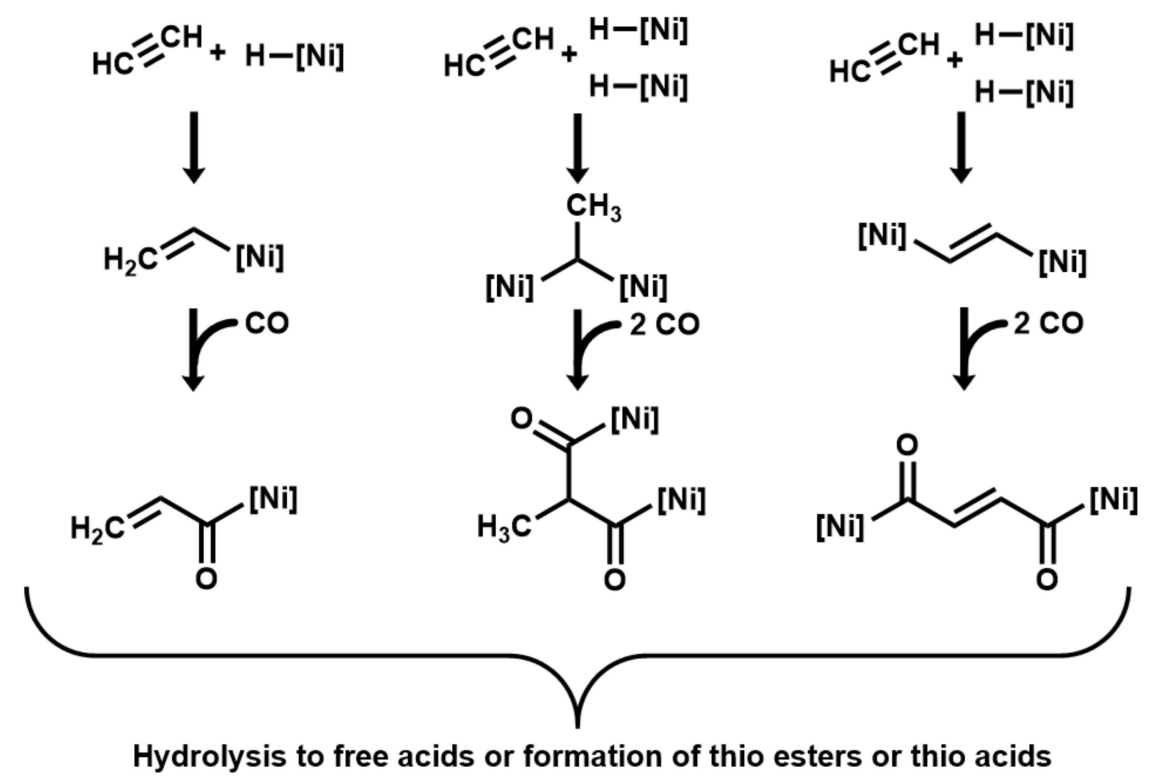

Figure 2. Proposed mechanism of acetylene/carboxydotrophic reactions on catalytic nickel centers. ([Ni] signifies a catalytic nickel center). 
In the context of a volcanic hydrothermal flow setting, the continuous supply of starting materials permits a metabolism with linear carbon fixation pathways that co-radiate from the ligand sphere of NiS. The products of these radial, linear pathways would have operated as pre-established stepping stones for later piecemeal cyclization. Subsequently, a scarcity of starting materials would have been compensated for by a conversion to autocatalytic $\mathrm{CO}_{2}$ fixation cycles, involving nutrient replacement, energy coupling, enzymatization, and the replacement of organo-metal activation by thioester activation without the violation of the principle of continuity. In our opinion, all extant carbon fixation cycles could be seen as successors of this primordial linear reaction system.

Supplementary Materials: The following are available online at http://www.mdpi.com/2075-1729/10/4/35/s1. Table S1. Metabolic products of the nickel-catalyzed reaction of acetylene with carbon monoxide. Figure S1. Formation of methyl thioacetate (thioacetic acid S-methyl ester) from $\mathrm{HC} \equiv \mathrm{CH}$ and $\mathrm{CH} 3 \mathrm{SH}$ in the presence of NiS. Figure S2. Comparison of the reductive acetyl-CoA pathway and the proposed primordial reaction mechanism to thioacetate. Figure S3. Reductive tricarboxylic acid cycle. Figure S4. 3-Hydroxpropinate/4-hydroxybutyrate cycle. Figure S5. Dicarboxylate/4-hydroxbutyrate cycle. Figure S6. 3-Hydroxypropionate bicycle.

Author Contributions: Conceptualization, C.H., W.E., and G.W.; data curation, J.S., T.G., C.M., and C.M.S.; funding acquisition, C.H.; investigation, J.S. and T.G.; methodology, J.S.; supervision, C.H.; visualization, T.G.; writing - original draft, C.H.; writing-review and editing, C.H., W.E. and G.W. All authors read, commented on and jointly approved submission of this article.

Funding: This research was funded by the Hans-Fischer-Gesellschaft (D-Munich) and the Deutsche Forschungsgemeinschaft (DFG, German Research Foundation)—Project-ID 364653263-TRR 235.

Conflicts of Interest: The authors declare no conflict of interest.

\section{References}

1. Braakman, R.; Smith, E. The emergence and early evolution of biological carbon-fixation. PLoS Comput. Biol. 2012, 8, e1002455. [CrossRef] [PubMed]

2. Varma, S.J.; Muchowska, K.B.; Chatelain, P.; Moran, J. Native iron reduces $\mathrm{CO}_{2}$ to intermediates and end-products of the acetyl-CoA pathway. Nat. Ecol. Evol. 2018, 1019-1024. [CrossRef] [PubMed]

3. Preiner, M.; Igarashi, K.; Muchowska, K.B.; Yu, M.; Varma, S.J.; Kleinermanns, K.; Nobu, M.K.; Kamagata, Y.; Tüysüz, H.; Moran, J.; et al. A hydrogen-dependent geochemical analogue of primordial carbon and energy metabolism. Nat. Ecol. Evol. 2020, 4, 534-542. [CrossRef] [PubMed]

4. Mukhin, L.M. Volcanic processes and synthesis of simple organic compounds on primitive earth. Orig. Life Evol. Biosph. 1976, 7, 355-368. [CrossRef] [PubMed]

5. Igari, S.; Maekawa, T.; Sakata, S. Light hydrocarbons in fumarolic gases: A case study in the kakkonda geothermal area. Chikyukagau 2000, 34, 103-109.

6. Oremland, R.S.; Voytek, M.A. Acetylene as fast food: Implications for development of life on anoxic primordial earth and in the outer solar system. Astrobiology 2008, 8, 45-58. [CrossRef]

7. Hollemann, A.F.; Wiberg, E.; Wiberg, N. Lehrbuch der Anorganischen Chemie, 102nd ed.; Walter de Gryter: Berlin, Germany, 2007; pp. 1243-1247.

8. Geisberger, T.; Diederich, P.; Steiner, T.; Eisenreich, W.; Schmitt-Kopplin, P.; Huber, C. Evolutionary steps in the analytics of primordial metabolic evolution. Life 2019, 9, 50. [CrossRef]

9. Huber, C.; Kraus, F.; Hanzlik, M.; Eisenreich, W.; Wächtershäuser, G. Elements of metabolic evolution. Chemistry 2012, 18, 2063-2080. [CrossRef]

10. Scheidler, C.; Sobotta, J.; Eisenreich, W.; Wächtershäuser, G.; Huber, C. Unsaturated C-3,5,7,9-monocarboxylic acids by aqueous, one-pot carbon fixation: Possible relevance for the origin of life. Sci. Rep. 2016, 6 . [CrossRef]

11. Ljungdahl, L.G.; Wood, H.G. Total synthesis of acetate from $\mathrm{CO}_{2}$ by heterotrophic bacteria. Annu. Rev. Microbiol. 1969, 23, 515-538. [CrossRef]

12. Huber, C.; Wächtershäuser, G. Activated acetic acid by carbon fixation on (Fe,Ni)S under primordial conditions. Science 1997, 276, 245-247. [CrossRef] [PubMed]

13. Heinen, W.; Lauwers, A.M. Organic sulfur compounds resulting from the interaction of iron sulfide, hydrogen sulfide and carbon dioxide in an anaerobic aqueous environment. Orig. Life Evol. Biosph. 1996, 26, 131-150. [CrossRef] [PubMed] 
14. Fuchs, G.; Stupperich, E.; Eden, G. Autotrophic $\mathrm{CO}_{2}$ fixation in Chlorobium limicola. Evidence for the operation of a reductive tricarboxylic acid cycle in growing cells. Arch. Microbiol. 1980, 128, 64-71. [CrossRef]

15. Kockelkorn, D.; Fuchs, G. Malonic semialdehyde reductase, succinic semialdehyde reductase, and succinyl-coenzyme a reductase from Metallosphaera sedula: Enzymes of the autotrophic 3-Hydroxypropionate/4-Hydroxybutyrate cycle in sulfolobales. J. Bacteriol. 2009, 191, 6352. [CrossRef]

16. Huber, H.; Gallenberger, M.; Jahn, U.; Eylert, E.; Berg, I.A.; Kockelkorn, D.; Eisenreich, W.; Fuchs, G. A dicarboxylate/4-hydroxybutyrate autotrophic carbon assimilation cycle in the hyperthermophilic Archaeum Ignicoccus hospitalis. Proc. Natl. Acad. Sci. USA 2008, 105, 7851-7856. [CrossRef]

17. Strauss, G.; Fuchs, G. Enzymes of a novel autotrophic $\mathrm{CO}_{2}$ fixation pathway in the phototrophic bacterium Chloroflexus aurantiacus, the 3-hydroxypropionate cycle. Eur. J. Biochem. 1993, 215, 633-643. [CrossRef]

18. Wächtershäuser, G. Evolution of the first metabolic cycles. Proc. Natl. Acad. Sci. USA 1990, 87, 200. [CrossRef]

19. Fuchs, G. Alternative pathways of carbon dioxide fixation: Insights into the early evolution of life? Annu. Rev. Microbiol. 2011, 65, 631-658. [CrossRef]

20. Berg, I.A. Ecological aspects of the distribution of different autotrophic $\mathrm{CO}_{2}$ fixation pathways. Appl. Environ. Microbiol. 2011, 77, 1925-1936. [CrossRef]

21. Hügler, M.; Sievert, S.M. Beyond the calvin cycle: Autotrophic carbon fixation in the ocean. Annu. Rev. Mar. Sci. 2011, 3, 261-289. [CrossRef]

22. Muchowska, K.B.; Varma, S.J.; Chevallot-Beroux, E.; Lethuillier-Karl, L.; Li, G.; Moran, J. Metals promote sequences of the reverse krebs cycle. Nat. Ecol. Evol. 2017, 1, 1716-1721. [CrossRef]

23. Keller, M.A.; Kampjut, D.; Harrison, S.A.; Ralser, M. Sulfate radicals enable a non-enzymatic krebs cycle precursor. Nat. Ecol. Evol. 2017, 1, 83-91. [CrossRef] [PubMed]

24. Muchowska, K.B.; Varma, S.J.; Moran, J. Synthesis and breakdown of universal metabolic precursors promoted by iron. Nature 2019, 569, 104-107. [CrossRef] [PubMed]

25. Jensen, M.M.; Thamdrup, B.; Dalsgaard, T. Effects of specific inhibitors on anammox and denitrification in marine sediments. Appl. Environ. Microbiol. 2007, 73, 3151-3158. [CrossRef] [PubMed]

26. Schink, B.; Kroneck, P.M. Exploring the active site of the tungsten, iron-sulfur enzyme acetylene hydratase. J. Bacteriol. 2011, 193, 1229-1236. [CrossRef]

27. Rosner, B.M.; Schink, B. Purification and characterization of acetylene hydratase of Pelobacter acetylenicus, a tungsten iron-sulfur protein. J. Bacteriol. 1995, 177, 5767. [CrossRef]

28. Akob, D.M.; Sutton, J.M.; Fierst, J.L.; Haase, K.B.; Baesman, S.; Luther, G.W., III; Miller, L.G.; Oremland, R.S. Acetylenotrophy: A hidden but ubiquitous microbial metabolism? FEMS Microbiol. Ecol. 2018, 94, fiy103. [CrossRef]

29. Holloway, J.R.; Blank, J.G. Application of experimental results to coh species in natural melts. Rev. Mineral. 1994, 30, 187.

30. Wächtershäuser, G. On the chemistry and evolution of the pioneer organism. Chem. Biodivers. 2007, 4, 584-602. [CrossRef]

31. Cox, P.A. The elements. Their origin, abundance, and distribution. In The Elements. Their Origin, Abundance, and Distribution; Cox, P.A., Ed.; Oxford University Press: Oxford, UK, 1989.

32. Hazen, R.M. Evolution of minerals. Sci. Am. 2010, 302, 58-65. [CrossRef]

33. Boer, J.L.; Mulrooney, S.B.; Hausinger, R.P. Nickel-dependent metalloenzymes. Arch. Biochem. Biophys. 2014, 142-152. [CrossRef] [PubMed]

34. Huber, C.; Wächtershäuser, G. Primordial reductive amination revisited. Tetrahedron Lett. 2003, 44, 1695-1697. [CrossRef]

35. Bernardi, F.; Bottoni, A.; Nicastro, M.; Rossi, I.; Novoa, J.; Prat, X. Theoretical study of the mechanism of carbonyl insertion reactions catalyzed by nickel complexes. Organometallics 2000, 19, 2170-2178. [CrossRef]

(C) 2020 by the authors. Licensee MDPI, Basel, Switzerland. This article is an open access article distributed under the terms and conditions of the Creative Commons Attribution (CC BY) license (http://creativecommons.org/licenses/by/4.0/). 